肝 echinococcosis の自然治癒例にみられた重複胆囊の 1 例

国立久留米病院外科, 久留米大学第 1 病理*

$\begin{array}{lllllll}\text { 内田 } & \text { 立生 } & \text { 吉田 } & \text { 晃治 } & \text { 野中 道泰 } & \text { 淵上 } & \text { 量三 } \\ \text { 田代 } & \text { 和弘 } & \text { 野口 } & \text { 秀哉 } & \text { 浦口憲一郎 } & \text { 才津 } & \text { 秀樹 } \\ \text { 杉原 } & \text { 茂孝* } & & & & & \end{array}$

\title{
A CASE OF DOUBLE GALLBLADDER WITH SPONTANEOUS HEALING OF LIVER ECHINOCOCCOSIS
}

\author{
Tatsuo UCHIDA, Koji YOSHIDA, Michiyasu NONAKA, \\ Kazumi FUCHIGAMI, Kazuhiro TASIRO, Hideya NOGUCHI, \\ Kenichiro URAKUCHI, Hideki SAITSU and Sigetaka SUGIHARA
}

Department of Surgery, National Kurume Hospital

1st Department of Patholgy, Kurume University School of Medicine

索引用語：肝 echinococcosis, 重複胆囊

はじめに

Echinococcus は条虫の一種で 1 個の頭節と数個の 体節からなっている。その幼虫は包虫とも呼ばれとト などに寄生し各臟器に震胞性病変をきたし包虫症を起 こす。また，重複胆囊は先天異常のなかの形態異常の 一つであるが1926年に Boyden ${ }^{1 /} か ゙$ 剖検例 9,221 例中 2 例を報告し，臨床的に経験することはすくない。

今回, 肝 echinococcosisの自然治癒がみられ, 同時 に重複胆囊であることが確認された症例を経験したの で報告する。

$$
\begin{aligned}
& \text { 症例：79歳, 女性. } \\
& \text { 主訴：右季肋部痛. }
\end{aligned}
$$

既往歷: 29 歳に子宮筋腫, 卵巣腫瘍摘出, 73歳時に 肝囊胞を指摘され， computed tomography (CT) で 肝右葉に巨大な多房性の襄胞がみられ，そのなかに大 小さまざまな daughter cystsを認め中心部に hydatid sand がみられた（図 1). 好酸球増多和よび北海道立衛 生研究所にて血清学的に補体結合反応128倍, 間接血液 凝集抑制反応 4,096 倍, 免疫電気泳動法にて沈降線を認 め, 画像診断とあわせ肝 echinococcosis ${ }^{2}$ と診断され ている.しかし echinococcosis に対する外科的治療は

$<1988$ 年 2 月 10 日受理 $>$ 別刷請求先 : 内田 立生 广830 久留米市国分町 $155-1$ 国立久留米病院外科
図 $1 \mathrm{CT}$ 像 (昭和55年, 8 月). 肝右葉に巨大な多胞 性囊胞を認める。

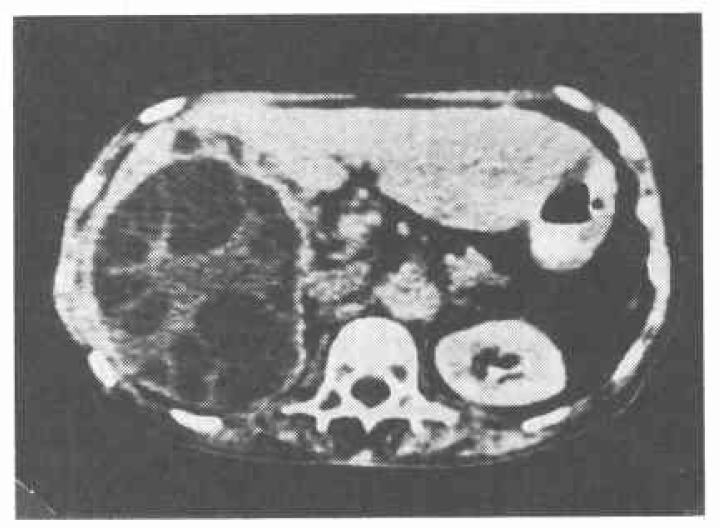

患者の同意が得られないまま放置されていた。

生活歴: 居住地は福岡県久留米市. 海外旅行の経験 無く東京以北に行ったことはない。

現病歷: 昭和61年 9 月 26 日, 右季胁部痛出現し近医 受診し超音波検査にて総胆管の拡張を指摘され当院を 紹介された。

入院時現症: 体格, 栄養中等度, 眼瞼結膜に負血, 眼球強膜に黄疸認めず。腹部は平坦で柔らかく, とく に異常所見を認めず。

入院時検查成績：尿および血液一般検查では異常を 
図 2 腹部超音波検查. 胆裹は adenomyomatosis の ために体部でくびれたようにみられ(黒矢印)，底部 側の胆囊は内部に不整な高ェコーな部分（白矢印） を伴った腫瘤像として描出された.

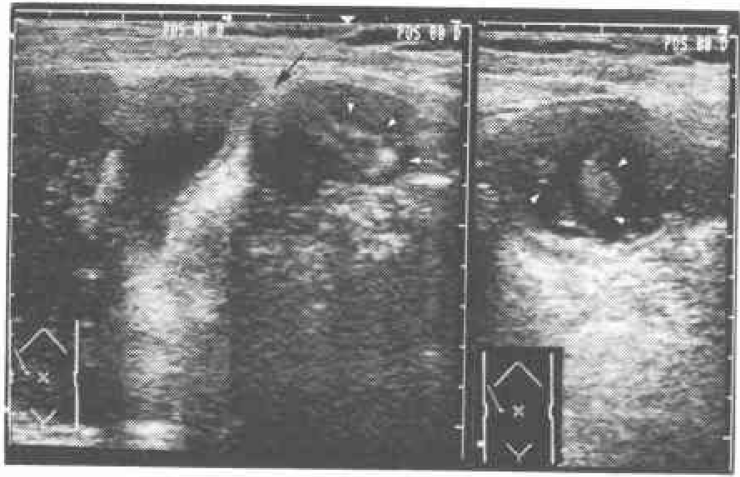

図 3 内視鏡的逆行性胆管造影. A：肝内外の胆管の 拡張がみられる，B：総胆管内に結石様陰影を認め る.
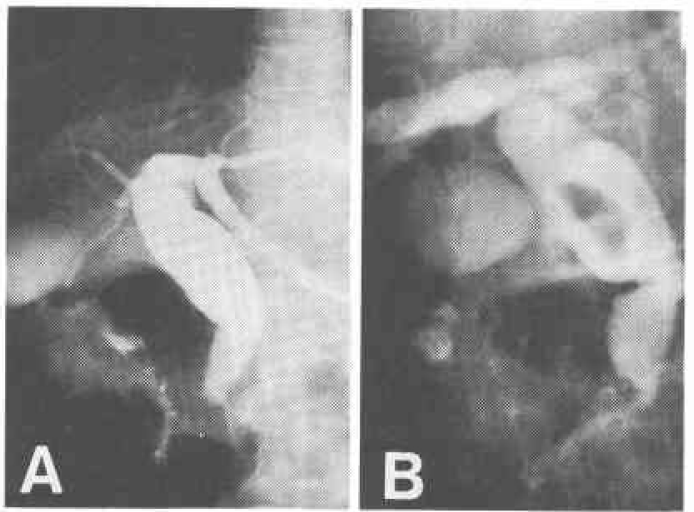

認めなかった．危疫血清学的にも陰性であった．

超音波検查：肋間操作で胆襄は adenomyomatosis のために体部でくびれたように認められ，肋間操作を さらに下にずらすと底部側の胆囊は内部に不整な高ェ コーな部分を伴った腫瘤像として描出された（図２）. また, 胆管の拡張と総胆管内の結石と思われる strong echoがみられた。

内視鏡的逆行性胆管造影：肝内外の胆管の拡張とそ の中に結石と思われる透亮像が認められ, 胆豄も造影 されている(図3).

$\mathrm{CT}$ : 肝内に 6 年前の巨大な囊胞はみられず, 肝右葉 の下縁の下に不整形な石灰化がみられるのみであっ た、また総胆管は2cm ほどまで拡張し総胆管内に high density structure か゚みられる。胆囊は軽度拡張し, 壁
図 4 CT 像. A：6 年前の巨大な霊胞はみられず肝 右葉の下縁に石灰化がみられるのみで(白矢印), 胆

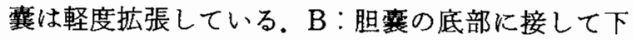
方に楕円形の cystic lesion（黒矢印）がみられる.
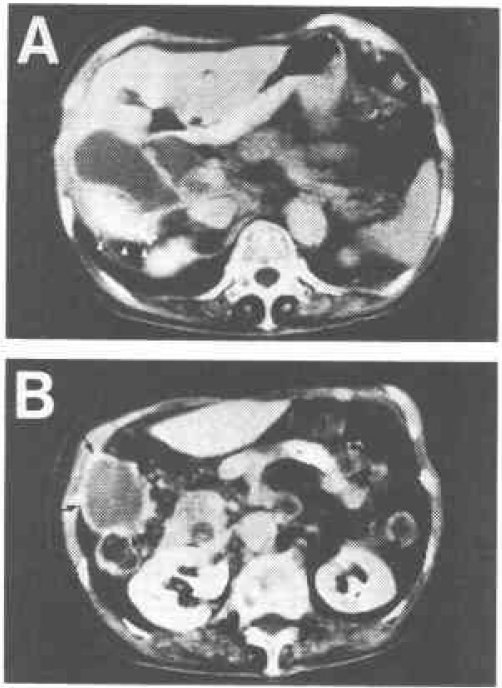

の肥厚がみられさらに底部に接して下方に棈円形の $6 \times 5 \mathrm{~cm}$ の腫瘤が認められた（図 4 ）。

腹部血管造影：選択的総肝動脈造影では肝右葉の萎 縮のみで，とくに所見を認めなかった。

以上より総胆管結石症と, 肝 echinococcosis と関係 があるのではないかとみられた腫瘤と診断し昭和 61 年 10月22日手術を施行した。

手術所見：肝は肉眼的に異常なく肝囊胞はみられな かった. 肝外胆管は $2.5 \mathrm{~cm}$ と拡張し, 胆囊の下方で十 二指腸外側に, 肝下面の側方寄りから出ている腫瘤を 認めた。 腫瘤は大腸, 十二指腸, 胆囊就よび周囲組織 との癒着がみられ，胆襄との瘉着は鈍的に簡単に剝離 できた。術中の腫瘤造影では胆管との交通ははっきり しなかった, 胆糞摘出術, 総胆管切開切石術, T-tube drainageを施行し，腫瘤摘出術を施行した（図５）.

切除標本所見：胆管結石はビリルビン石灰石で 3 個 認められた。摘出された胆囊は胆豪内に結石はなく, とくに所見を認めなかった。腫瘤は大きさ $8.5 \times 6 \times 5$ cmで囊胞状で内腔にゼリ一様物質がみられた（図 6 ).

病理組織学的所見：胆囊として摘出された臟器は壁 の構造および粘膜上皮は保たれており慢性胆囊炎の像 であるが，腫瘤として摘出された臓器は消化管として の構造に乏しく壁は線維成分で置換されている。しか 
図 5 手術所見. 1：訮下面からでている腫瘤を認め た. 2 : 胆襄. $3:$ 総胆管は $2.5 \mathrm{~cm}$ と抎張し結石が 3 個みられた。

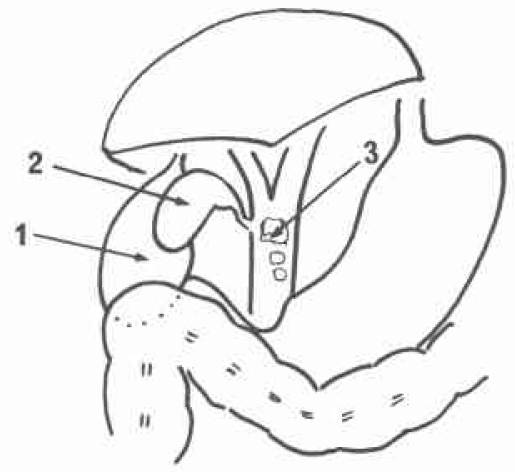

図 6 切除標本所見. A：腫瘤は囊胞状で底部，体部， 頸部を肉眼的に備えている，B：内腔にゼリ一様物 質がみられる。
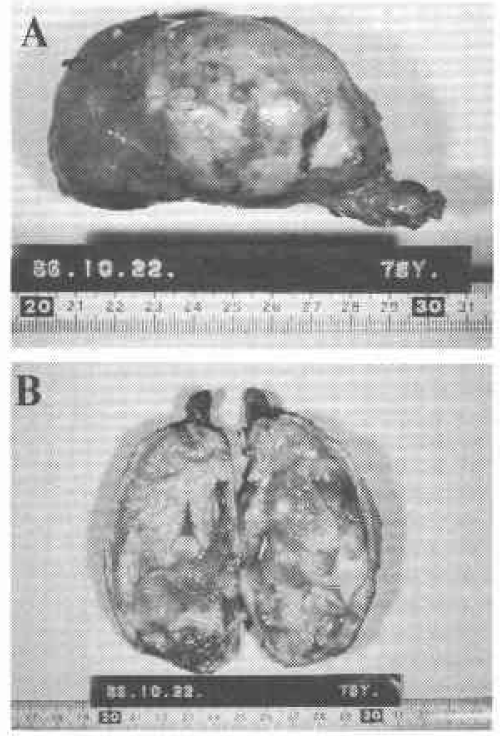

し，粘膜上皮および Rokitansky-Aschoff 洞の存在か ら胆囊の臓器所見が得られた（図 7,8).

術後経過：術後 1 年, 経過良好である。

\section{考察}

肝 echinococcosis は寄生虫症のなかで衰胞を形成 する唯一の疾患であり単包条虫と多包条虫の 2 種類が ある，前者は九州，四国地方に約70例の報告を見るが 最近の報告例は 1 例尚をみるに過ざず，後者は北海道 を中心に約250例発生している。これら成虫はイヌやキ ツネなどの腸管に寄生し，それらの肉食動物の排泄物

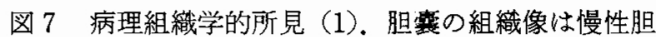
襄炎を呈す（上段， $\mathrm{HE} \times 10 ）$ ．腫瘤として摘出され た組織像は，壁は線維成分で置換されているが粘膜 上皮は保たれている（下段，HE×10）。

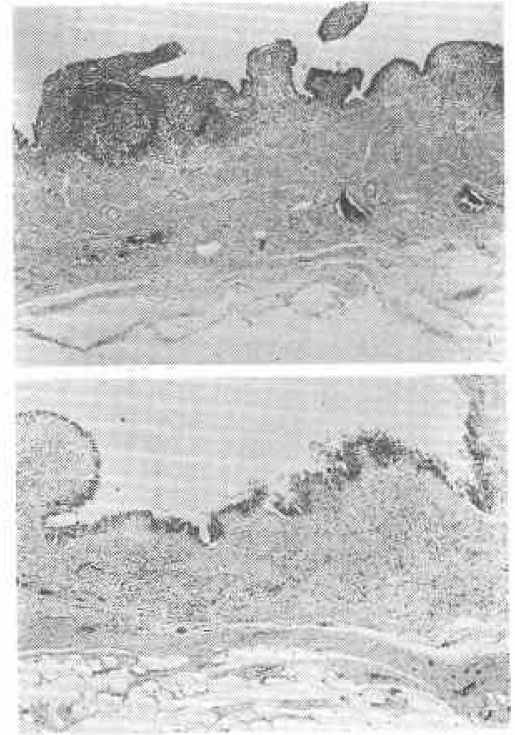

図 8 病理組織学的所見（2).腫瘤として摘出された 部に Rokitansky-Aschoff 洞がみられ，粘膜上皮の 存在から胆豊と診断した $(\mathrm{HE} \times 5)$.

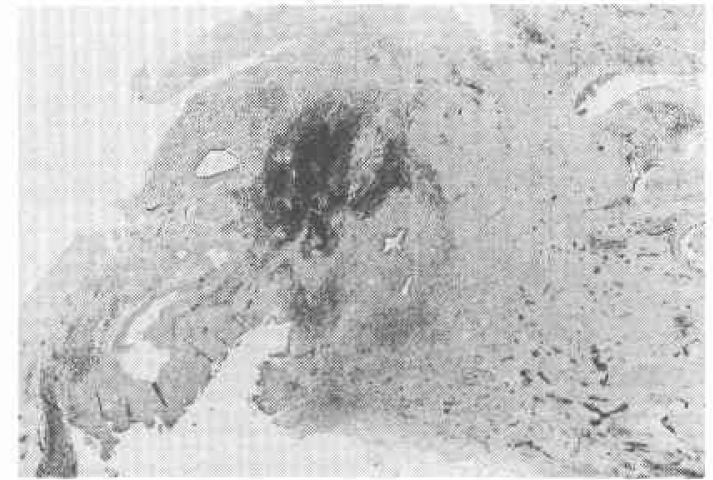

の虫卵を摂取するとその幼虫により echinococcosis を起こす。その臨床経過は比較的緩慢で感染後10-15 年を経て震胞が異常な大きさに達するまで無症状に経 過する場合が多く，本症例でも小児頭大とかなり大き くなるまで自覚症状，肝障害を認めていない。

多包虫肝 echinococcosis はその哄胞形成が budding outであり周囲組織の圧迫も顕著で，2次包虫に よる転移の頻度も高く，その病態は発育が遅いことを 
除けば肝悪性腫瘍とほぼ同じである ${ }^{4)}$ 。一方, 単包虫肝 echinococcosis は多包虫肝 echinococcosis $に$ 比べて まとまった報告は少なく，感染経路，治療，予後も不 明確な点が多い，治療ではとくに有効な薬物はなく， 外科的治療において壤胞摘出術のみで $90 \%$ 以上に良好 な結果が得られるかが，自然治㦄したという報告はみ あたらない. 本例は 6 年間, 外科的治療はもちろん投 薬もなくいわば放置された状態で自然治痖が見られた 貴重な症例であった。陳ら゙けは単包虫肝 echinococcosis を超音波像より 5 型に分類し， 1 型は multiloculated cystic pattern で母震内に娘囊がある typeで 娘囊の存在は肝包虫襄胞を確信しらる所見であると述 べている. 本例もこの分類の 1 型にあたりまた免疫血 清学的に陽性で, 内容液の成分や震胞壁の scolex の状 態は検索されていないが，地域性，良好な予後を考慮 して単包性肝 echinococcosis と考克られた。

重複胆囊は頻度としては動物では比較的多くみられ るが，ヒトでは Boyden ${ }^{11}$ が報告したように剖検例で $0.02 \%$ ，胆震造影陽性例で $0.03 \%$ と報告しきわめて少 ない，重複の型を見るとBoydenは 2 本の胆䧶管が合 流して胆管に入る型を $\mathrm{Y}$ 型とし別々に入る型を ductural type とに分類した。 また，Gross ${ }^{77}$ は1936年に 重複胆囊28例を集計し 6 型に分類し，そのうち C 型は 副胆襄管が直接肝に入っている型であるが，本症例は そのC型に相当すると思われた。胆囊と定義するため には諸家の報告がある。山本ら ${ }^{8)}$ は，(1)頸部に括いて弁 状構造を持つ. (2)頸部, 体部, 低部を肉眼的に備兄壁 に筋層を備える。(3)機能的には胆汁濃縮能を持つ，の 3つをあげているが，自験例で弁状構造や胆汁濃縮能 を証明しえていないと述べている。長谷川らのす同様 に定義し自験例で組織学的に明瞭な筋層が認められる

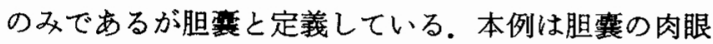
的形態は備えているが胆管との交通は明確でなく，ま た, 濃縮能も証明し党なかった。しかし組織学的に上 皮がみられ Rokitansky-Ascohoff 洞があることより 重複胆亳と診断した。
重複䏣囊は本邦では長谷川ら"9が1984年に31例を集 計し検討を加えているが，診断は手術時に偶然発見さ れた症例が11例（37.5\%）と最も多かった。本例も術 中に腫瘤として摘出され術後の病理組織学的検索に よって初めて重複胆囊と判明し, 術前, 術中にこの部 の腫瘤を見た場合常に重複胆囊の存在を念頭におくこ とが必要と思われた。

結語

6 年前に肝 echinococcosis の既往があり, 右季肋部 痛を主訴として来院し，総胆管結石症と右上腹部腫瘤 の診断を受け手術, 組織学的検査により重複胆震であ ることが確認され，また，同時に肝 echinococcosisの 自然治㦄もみられたので若干の考察を加え報告した。

\section{文 献}

1) Boyden EA: The accesary gallbladder-An embryological and comparative study of aberrant biliary vesicles occuring in mann and the domestic mammals. Am J Anat 38 : 177-231, 1926

2）真島康雄, 谷川久ー：エコー法の現況. Medicina $22: 2278-2282,1985$

3）入来 敦, 今山修平, 宮岡達也注：包虫症。西日 皮 $48: 9-12,1986$

4）中西昌美, 佐藤直樹：肝エキノコッカス症の病態 と治療.カレントテラピー $3: 1116-1122,1985$

5) Barros JL: Hydatid disease of the liver. Am J Surg $135: 597-600,1978$

6) 陳 敏華, 重 富偉, 李 建国活か：肝包虫症( $x$ キノコッカス症)の超音波診断。Jpn J Med Ultrasonics $13: 42-48,1986$

7) Gross RE: Congenital anomalies of the gallbladder. Arch Surg $32: 131-162,1938$

8）山本貞博, 小池明彦, 竹重言人ほか：乳頭状腺癌を 合併した重複胆㷶の 1 例. 双葉発生論との関連. 愛 知医大誌 $7: 263-268,1979$

9）長谷川洋, 前田正司, 中神一人注か：重複胆䧶の1 例之本邦報告例31例の検討。日臨外医会誌 45 ： 961-966, 1984 